Botany Research Journal 4 (1): 1-2, 2011

ISSN: 1995-4751

(C) Medwell Journals, 2011

\title{
Investigation on Quality and Quantity of Forest Types Common Hazel (Corylus avellana L.) in Foundogluo Forest, Iran
}

\author{
Ali Akbar Imani, Younes Rostamikia and Muharram Hoshyar \\ Islamic Azad University, Ardabil Branch, Ardabil, Iran
}

\begin{abstract}
The total forest area of Iran is approximately 12 million ha which make only $7.3 \%$ of the total land area. Foundoglu forest is a unique forest with 1773 ha and located at the and of western Elburz Mountain chains, in Ardabil province (North Eastern of Iran). For doing this research, we have organized a sampling to drive structural information of some quantitative and qualitative characteristics. Stand measurement was a systematic random sampling. With the sampling grid of $150 \times 200 \mathrm{~m}$ and plot area $500 \mathrm{~m}^{2}$ and the measurement of structural characteristics were done to get information on species, origin of sp., quality of sp., collar diameter, total height canopy cover, regeneration, slope aspect and altitude. Results showed that common hazel is distributed on site between 1370 and 1580 m.a.s.I. with $352.2 \mathrm{~mm}$ annul precipitation and mean annul temperature $9.7^{\circ} \mathrm{C}$ five vegetation types of Corylus-Quercus, Corylus-Fagus, Fagus-Corylus, Corylus-Acer and mixed Corylus were separated.
\end{abstract}

Key words: Common hazel, regeneration, diversity of woody speices, vegetation, Iran

\section{INTRODUCTION}

The total forest area of Iran is approximately 12 million ha which make only $7.3 \%$ of the total land area (Marvie-Mohadjer, 2005). However, it is rich country with aspect of plant biodiversity with almost 8000 vascular plants. Fandogluo forest is a unique forest with 1773 ha (Yousefpour et al., 2004) and located at the and of western Elburz Mountain chains in Ardabil province (Northwestern of Iran), the area smooth topography and climatically sub humid (Anonymous, 1984). Common hazel (Corylus avellana L.) is the most important tree species in Fandogluo forest. Common hazel is typically a shrub reaching $5 \mathrm{~m}$ tall but can reach $8 \mathrm{~m}$. The leaves are deciduas, rounded $6-13 \mathrm{~cm}$ long across $5-10 \mathrm{~cm}$, softly hairy on both surface (Sabeti, 1976). There are some study about forests, study of environmental adaption ecology (Moraghbi, 2001). In particular about phytosociology of Fandugluo forest (Teymourazadeh et al., 2004) and about succession of Beech stand (Anonymous, 1984).

\section{MATERIALS AND METHODS}

Study sites: The experimental forest is a 256 ha between longitudes $48^{\circ} 42^{\prime} 31^{\prime \prime}$ and $48^{\circ} 53^{\prime} 25^{\prime \prime}$ and latitudes $38^{\circ} 17^{\prime} 11^{\prime \prime}$ and $38^{\circ} 25^{\prime} 50^{\prime \prime}$. Minimum altitudes about $980 \mathrm{~m}$ and the maximum $1550 \mathrm{~m}$.a.s.1. the slope inclination in this sites is $5-35 \%$. Mean annual temperature is around $9.7^{\circ} \mathrm{C}$ while the mean annual rainfall is estimated to be around
$352.2 \mathrm{~mm}$ and high number of foggy days is particularly effective is supply water regimen. Dominant tree and shrub species in this region consist of Beech (Fagus orientalis Lipsky) Carpinus orientalis L., Quercus castane folia, Acer campestre L., Malus orientalis L., Quercus macranthera F. and M.

Methods: For doing this research, we have organized a sampling to drive structural information of some quantitative and qualitative characteristics. Stand measurement was a systematic-random sampling (Zobeiry, 2002). With the sampling grid of $150 \times 200 \mathrm{~m}$ and plot area $500 \mathrm{~m}^{2}$ and the measurement of structural characteristics were done to get information on species, origin of sp. quality of sp., collar diameter, total hight, canopy cover, regeneration, slope, aspect and altitude.

\section{RESULTS}

The results of these measurement is shown in the Table 1 and shows that how different are the measured stands. Kuchler physiognomic method in 1988 was used for forest classification totally, five different types of

Table 1: Five types of common hazel in study site

\begin{tabular}{lclc}
\hline Foerst type & Slope $(\%)$ & Aspect & Range of altitude m.a.s.1 \\
\hline Corylus-Quercus & $5-35$ & S,NS,N & $1380-1460$ \\
Corylus-Fagus & $10-60$ & N,NW,NE & $1370-1580$ \\
Fagus-Corylus & $35-55$ & $\mathrm{~N}$ & $1385-1560$ \\
Corylus-Acer & $5-20$ & $\mathrm{~S}$ & $1440-1500$ \\
Mixed Corylus & $10-45$ & $\mathrm{~N}, \mathrm{~S}$ & $1390-1485$ \\
\hline
\end{tabular}

Corresponding Author: Ali Akbar Imani, Islamic Azad University, Ardabil Branch, Ardabil, Iran 
Bot. Res. J., 4 (1): 1-2, 2011

Table 2: Qualitative and quantative characteristics of diffremt forest types Diversity No. of of woody woody species Canopy Renegeration

\begin{tabular}{lcccc} 
Foerst type & $\begin{array}{c}\text { of } \\
\text { speices }\end{array}$ & $\begin{array}{c}\text { coody sa } \\
\left(\mathrm{n} \mathrm{ha}^{-1}\right)\end{array}$ & $\begin{array}{c}\text { caver (\%) } \\
\text { coved. origin }\end{array}$ \\
\hline Corylus-Quercus & 23 & 2400 & 65 & 13.4 \\
seed
\end{tabular}

$\begin{array}{llllr}\text { Corylus-Fagus } & 24 & 2951 & 778 & 8.5\end{array}$

$\begin{array}{lllll}\text { Fagus-Corylus } & 14 & 1898 & 54 & 13.5\end{array}$

Corylus-Acer $\quad 17$

\begin{tabular}{lllll} 
Mixed Corylus & 12 & 3580 & 83 & 15.5 \\
\hline
\end{tabular}

Table 3: Qualitative and quantities characteristics of common hazel in study site

\begin{tabular}{lcccc}
\hline Forest type & $\begin{array}{c}\text { Frequency } \\
\text { of corylus } \\
(\%)\end{array}$ & $\begin{array}{c}\text { Average } \\
\text { of collar } \\
\text { diameter (cm) }\end{array}$ & $\begin{array}{c}\text { Average } \\
\text { of height } \\
\text { (m) }\end{array}$ & $\begin{array}{c}\text { Average of } \\
\text { number of } \\
\text { sprout on stump }\end{array}$ \\
\hline Corylus-Quercus & 25.5 & 10.5 & 4.9 & 33 \\
Corylus-Fagus & 61.5 & 9.0 & 4.5 & 28 \\
Fagus-Corylus & 28.5 & 18.0 & 4.1 & 22 \\
Corylus-Acer & 33.5 & 13.0 & 3.8 & 31 \\
Mixed Corylus & 56.0 & 10.0 & 3.6 & 38 \\
\hline
\end{tabular}

Corylus-Quercus, Corylus-Fagus, Fagus-Corylus, Corylus-Acer and mixed Corylus were separated. The results of inventory showed that distribution range of altitude varies between 1370-1580 m.a.s.1 (Table 1). The highest common hazel trees were observed on Corylus-Quercus type $(4.9 \mathrm{~m})$ and Corylus-Fagus type $(4.5 \mathrm{~m})$, respectively. The most frequency of Corylus (\%) was observed on Corylus-Fagus $(61.5 \%)$ and the most number of sprouts on stump were observed on Mixed Corylus type (Table 2 and 3 ).

\section{CONCLUSION}

Ardabil province where is located in northwestern of Iran contains 1.8 million hectare. Fandogluo forest that located in the east Ardabil city is very important of ecological condition and specific fauna and flora. This non commercial forest including species such as common hazel, oak, beech, hornbeam, maple trees. Like other investigations of Yousefpour et al. (2004) and Teymourazadeh et al. (2004) in this forest, diversity of woody species is very high and Average of number of sprout on stump is showed that forest structure in this forest is coppice system (Anonymous, 1984; Teymourazadeh et al., 2004).

\section{ACKNOWLEDGEMENT}

This study was supported by Islamic Azad University, Ardabil Branch, Ardabil, Iran in 2010.

\section{REFERENCES}

Anonymous, 1984. The comprehensive forestry plan of fandoghluo forest. Forestry Service of the East Azerbaijan Province.

Marvie-Mohadjer, M.R., 2005. Silviculture. 1st Edn., Tehran University Press, Tehran, Iran, ISBN: 964-035098-2 (In Persian).

Moraghbi, F., 2001. Study of environmental adaption ecology and common Hazel phytosociologiacl in North of Iran. Ph.D. Thesis, Azad University.

Sabeti, H., 1976. Forests, Trees and Shrubs of Iran. Agriculture and Natural Resources Research Organization Press, Iran.

Teymourazadeh, A., M. Akbariniya, S.M. Hosseini and M. Tabari, 2004. Study of phytosciology of Eastern Ardabil, Iran. J. Agric. Sci. Nat. Resour., E104: 135-146.

Yousefpour, R., M.R. Marvie-Mohadjer and K.H. SaghebTalebi, 2004. Dynamics of oriental Beech stands in Fandougluo forest, Ardebil, Iran. Proceeding of the 7th International Beech Symposium. Tehran. Iran.

Zobeiry, M., 2002. Forest Biometry. Publication of Tehran University, Iran, pp: 411 (In Persian). 